\title{
Petrographic characteristics and depositional environment of No. 6 coal from Xiaoyugou Mine, Jungar Coalfield, China
}

\author{
Yanzhong Zhang $\cdot$ Lin Xiao
}

Received: 22 July 2014/Revised: 7 November 2014/Accepted: 10 November 2014/Published online: 26 December 2014

(C) The Author(s) 2014. This article is published with open access at Springerlink.com

\begin{abstract}
This paper discussed the petrographic characteristics of No. 6 coal from the Xiaoyugou mine, Jungar Coalfield, Ordos Basin, China. 10 samples (7 coal, 1 parting mudstone and 2 floor mudstone) were analysed by microscopical and geochemical methods. Four maceral compositions and several associated elements parameters were selected as indicators and corresponding diagrams were drawn to explicate the sedimentary environment. The results indicate that the maceral is dominated by vitrinite and minerals are mainly kaolinite in the No. 6 coal. The sedimentary facies vary from barrier island system to tidal-flat which is a deposition process of water body shallowing and the coal-forming plants are herbs and woody plants formed in swamps.
\end{abstract}

Keywords Xiaoyugou coal mine $\cdot$ Maceral $\cdot$ Sedimentary environment $\cdot$ Jungar coalfield

\section{Introduction}

In recent years, coal associated with $\mathrm{Li}, \mathrm{Ga}$ and $\mathrm{REY}$ $(\mathrm{REE}+\mathrm{Y})$ ore deposits have been found in Jungar Coalfield, China (Dai et al. 2006a; Sun et al. 2009, 2010a, 2012a, b, c, 2013; Seredin et al. 2013). In order to study the enrichment mechanism of the trace elements, the depositional environments of the peat moors should be well known. Coal petrology is a very important way to analyze peat moors and associated elements (Zhao et al. 2014).

Ordos Basin is located in the west of the Northern China Platform. Jungar Coalfield is situated on the northeastern margin of Ordos Basin. The coalfield is $65 \mathrm{~km}$ long $(\mathrm{N}-\mathrm{S})$ and $26 \mathrm{~km}$ wide (W-E), with a total area of $1,730 \mathrm{~km}^{2}$. The coal-bearing strata belong to Permo-Carboniferous, which were deposited in marine-terrigenous facies. Dai et al. $(2006 \mathrm{~b}, 2008)$ studied the geochemistry and miner-

Y. Zhang $\cdot$ L. Xiao $(\square)$

Key Laboratory of Resource Exploration Research of Hebei Province, Hebei University of Engineering, Handan 056038, China

e-mail: xiaolin@hebeu.edu.cn alogy of the No. 6 coal and its coal combustion products from the Heidaigou and Haerwusu Surface Mines in the Jungar Coalfield. But the Petrographic characteristics and depositional environment of Xiaoyugou have not been studied so far. Xiaoyugou Mine (Fig. 1) is situated in the northeast margin of Jungar coalfield. The mine area is $2.79 \mathrm{~km}$ long $(\mathrm{N}-\mathrm{S})$ and $1.39 \mathrm{~km}$ wide (W-E), with a total area of $3.9893 \mathrm{~km}^{2}$. The coal-bearing strata include Benxi Formation, Taiyuan Formation and Shanxi Formation with a total thickness of 110-160 m (Fig. 2). The No. 6 coal is the main coal seam, with the thickness of approximate $11 \mathrm{~m}$.

\section{Sampling and methods}

Sampling was conducted from the floor to the center of the coal field about $5 \mathrm{~m}$. 10 samples ( 7 coal, 1 parting mudstone and 2 floor mudstone) were collected from the workface of No. 6 coal in the Xiaoyugou Mine, Jungar Coalfield, Ordos Basin following the Chinese Standard Method GB482-2008. From the bottom to top, the 7 samples of coal are XYG6-1 to XYG6-7, and 2 floor samples are XYG-F1 and XYG-F2, respectively. The only parting sample was gotten between XYG6-1 and XYG6-2. The 


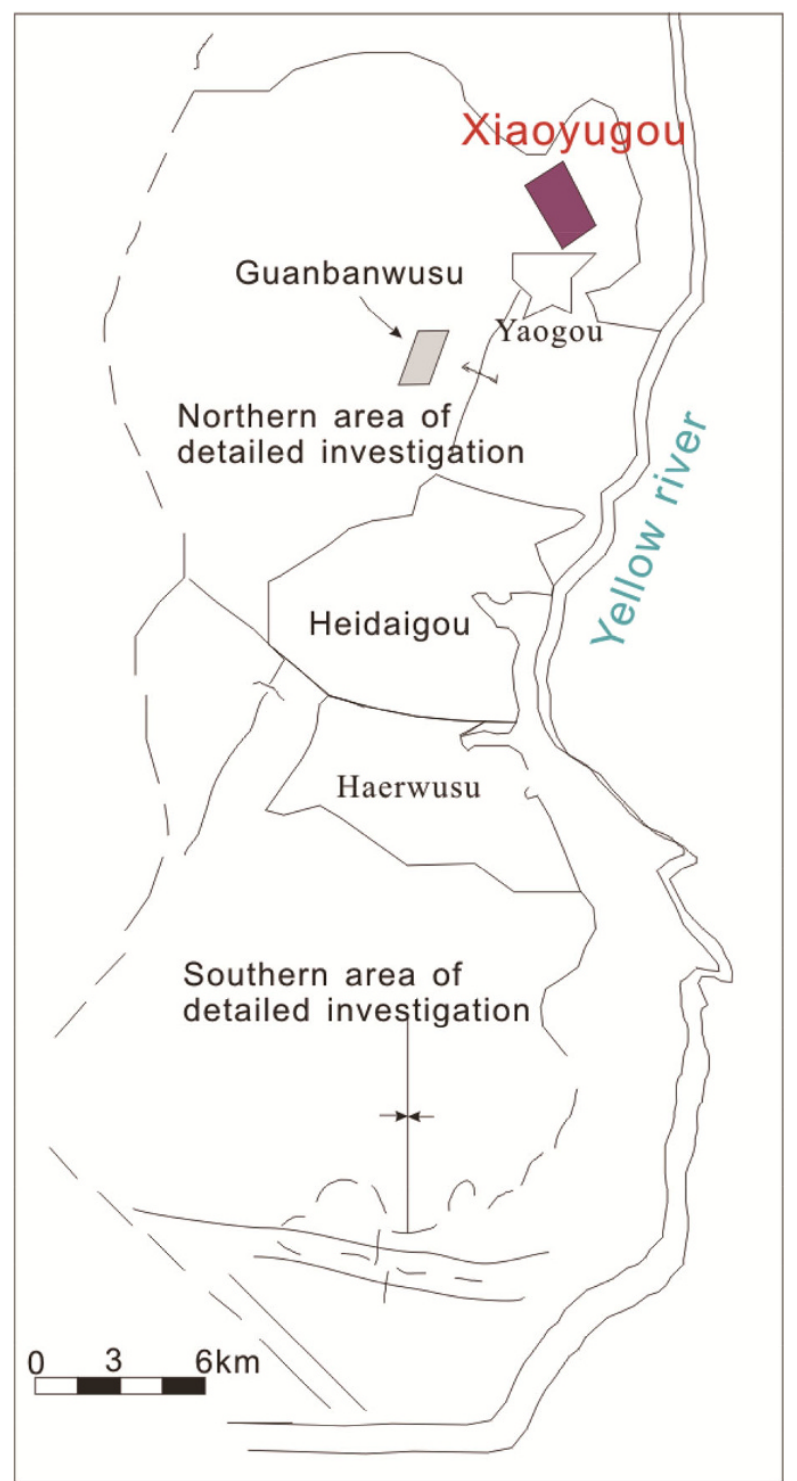

Fig. 1 Location of the Xiaoyugou Mine, Jungar Coalfield, Inner Mongolia, China

polished section are made of epoxy-bound pellets with coal particles which were crushed and ground to between $0.25-1 \mathrm{~mm}$ and prepared to the final fineness with $0.05 \mu \mathrm{m}$ alumina. The macerals were analyzed on polished pellet under reflected white light using a swift point counter (Sun et al. 2002). The maceral groups were determined by counting more than 500 points each sample. Secondly, only the macerals of fluorescing liptinite was measured under blue light excitation of $450-490 \mathrm{~nm}$ wavelength (Sun 2003). Some representative and special maceral pictures (Fig. 3) were taken and the vitrinite reflectance $\left(R_{\mathrm{o}}\right)$ which was deemed to represent the maturation of samples was determined using an oil immersion objective $(32 \times)$ with a $546 \mathrm{~nm}$ filter. The measurement was calibrated using a

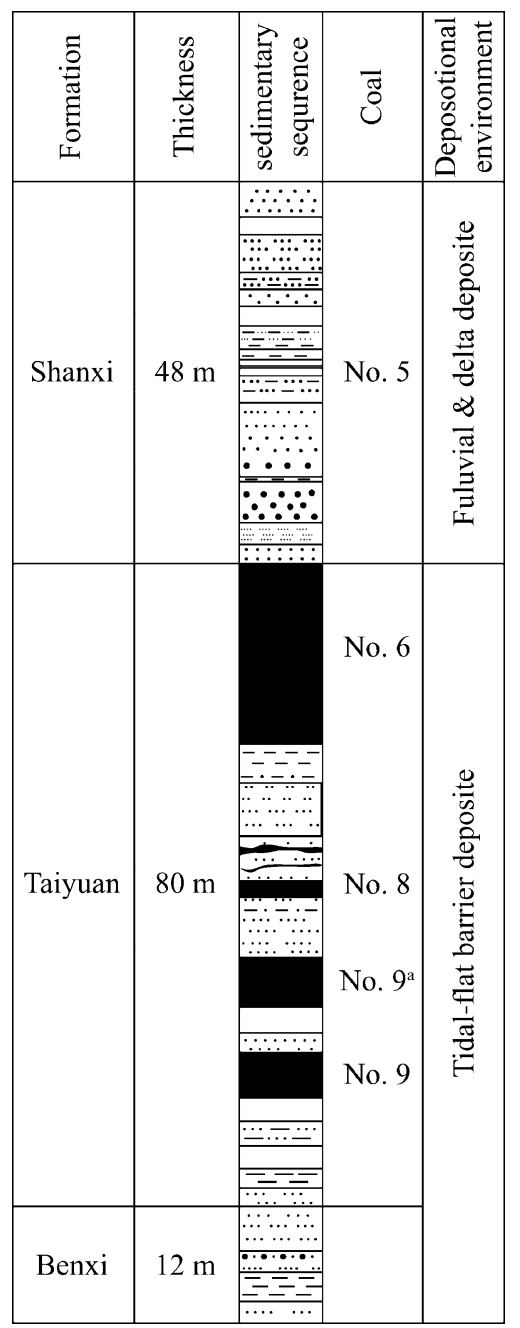

Fig. 2 Stratigraphic column and sedimentary environment of the Xiaoyugou mine in Junger Coalfield (Ye et al. 1997)

Leitz glass standard $\left(R_{\mathrm{o}}=0.89 \%\right)$ (Sun et al. 2010b). The experiment was finished at the Key Laboratory of Resource Survey and Research of Hebei Province.

Samples for geochemical analysis in Xiaoyugou mine were crushed and ground to less than 200 mesh. X-ray fluorescence spectrometric analysis was used to judge the oxides of the major elements, including $\mathrm{Na}, \mathrm{Mg}, \mathrm{Al}, \mathrm{Si}, \mathrm{Fe}$, Ca, K, Mn, Ti, and P (Dai et al. 2006b).

\section{Results and discussion}

3.1 Coal chemistry and vitrinite reflectance

According to the proximate analysis, the moisture content and volatile matter rise from XYG6-1 to XYG6-7 of the No. 6 coal. The vitrinite reflectance can reflect the maturity 

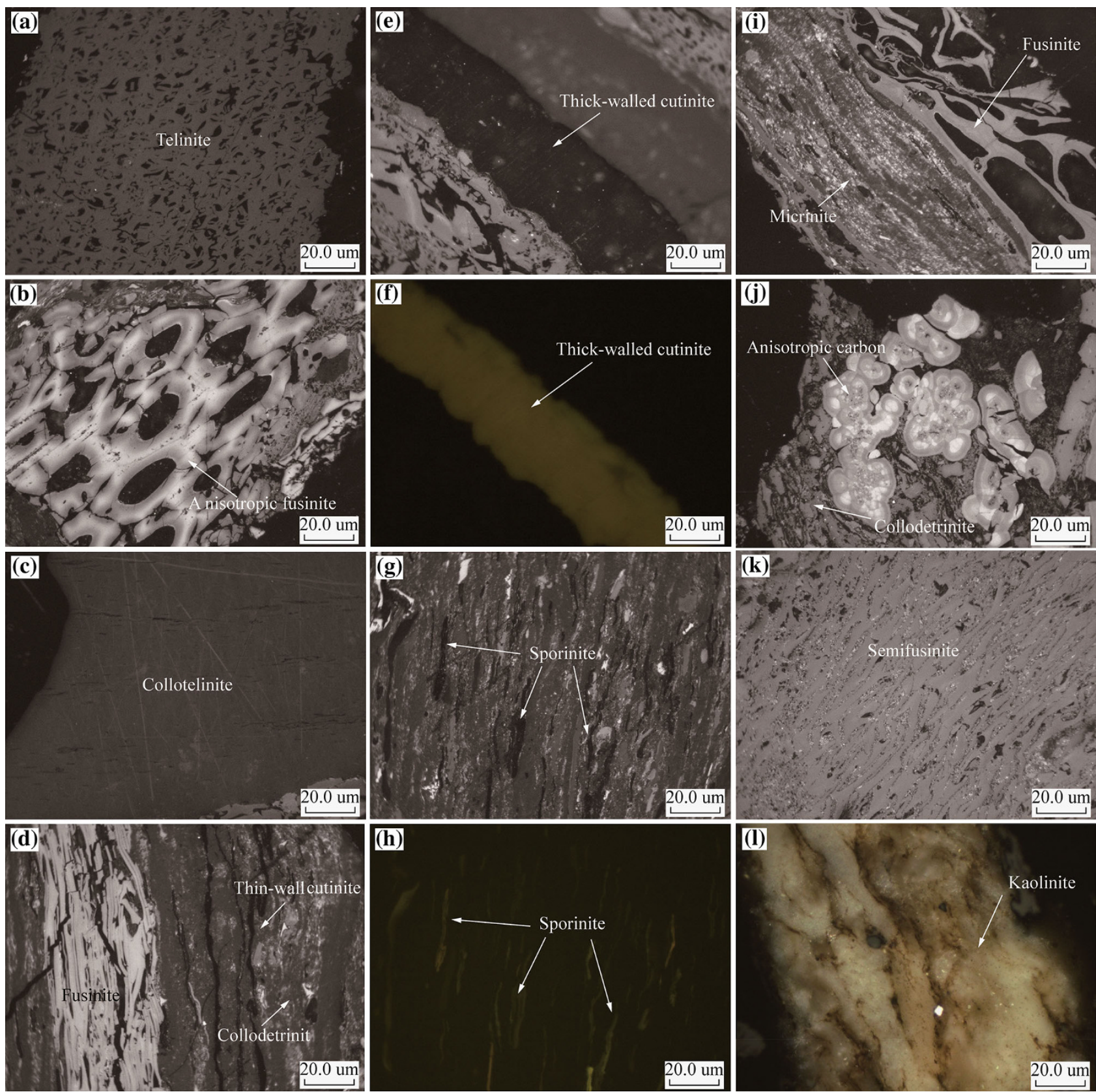

Fig. 3 Macerals of the samples from the No. 6 coal under oil immersion reflected light. a telinite in XYG6-7; b fusinite with signs of oxidized shows obvious anisotropy in XYG6-8; c colotelinite in XYG6-5; $\mathbf{d}$ fusinite on the left and thin-wall cutinite embedded in the colodetrinite on the right in XYG68; $\mathbf{e}, \mathbf{f}$ thick-walled cutinite in XYG6-4; $\mathbf{g}, \mathbf{h}$ sporinite filled in colodetrinite in XYG6-6; $\mathbf{i}$ micrinite filled in colodetrinite and fusinite in XYG6-8; j anisotropic only appeared in XYG6-5; $\mathbf{k}$ semifusinite filled with micrinite in XYG6-5; $\mathbf{1}$ kaolinite in XYG6-6

of coal. The random vitrinite reflectance $\left(R_{\mathrm{o}}\right)$ and the average volatile matter value of No. 6 are $0.59 \%$ and $26.93 \%$ respectively, indicating that the rank of the coal is medium-volatile bituminous.

The No. 6 coal is a low-ash and low-sulfur coal, according to Chinese Standard GB 15224.1-2010 (coals with ash yields $10.01 \%-20.00 \%$ are low-ash coal) and GB/T 15224.2-2004 (coals with total sulfur content
$0.5 \%-0.9 \%$ are low-sulfur coal). The XYG6-2 is higher in sulfur content $(1.26 \%)$ than other samples $(0.27 \%-0.73 \%)$.

\subsection{Maceral composition}

The maceral characteristics of No. 6 coal of Xiaoyugou Mine, Jungar Coalfield (Table 1) are as follows: 


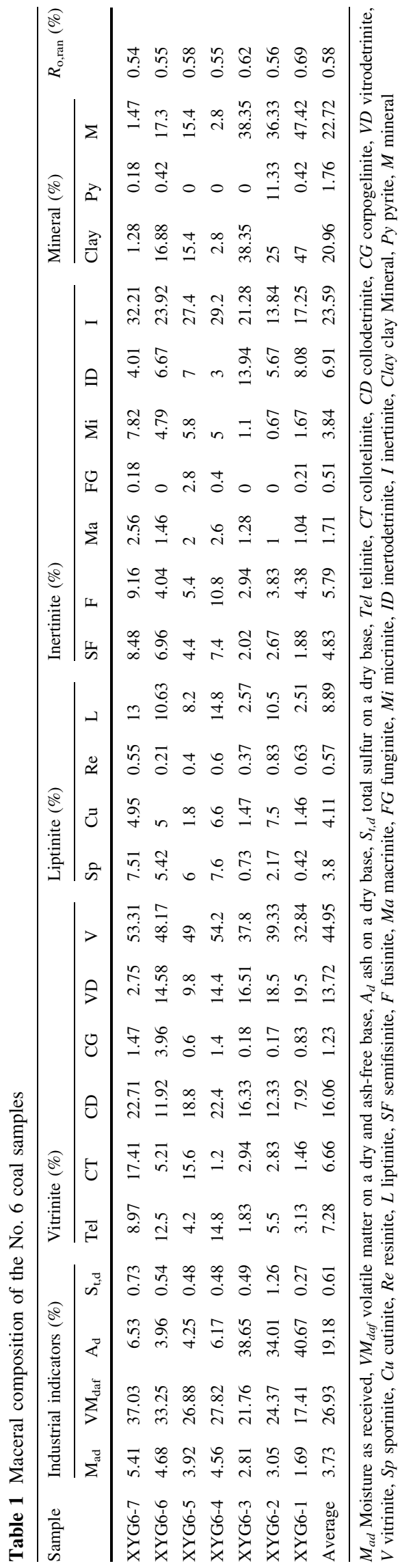

The maceral is mainly composed of vitrinite with an average content of $44.9 \%$ varying from $30.83 \%$ to $54.20 \%$. Desmocollinite $(7.93 \%-22.71 \%)$ and vitrodetrinite $(2.75 \%-18.50 \%)$ are the dominant vitrinite macerals with average content of $15.63 \%-13.43 \%$, respectively. From XYG6-1 to XYG6-7, the content of telinite and collotelinite tends to increase.

The amount of inertinite reaches up to $23.16 \%$ dominated by fusinite $(5.65 \%)$ and inertodetrinite $(6.77 \%)$, and semifusinite only next to fusinite with a content of $4.69 \%$. The micrinite is relatively high with a content of $3.84 \%$, especially in samples XYG6-4-XYG6-7 with an average content of $5.45 \%$. There was a sign of being oxidized in inertinites, such as fusinite in all samples, macrinite in XYG6-5.

Due to the high amount of micrinite, it is necessary to analyse the cause of formation, for the micrinite distributed into collotelinite, collodetrinite, the clay mineral filling in telinite. Some micrinite, which can be called anisotropy micrinite for the anisotropy in No. 6, is clearly obvious (Xiao and Ren 1988). Hydrogen-rich maceral in coal with great thermal activity is the material basis of forming micrinite such as bituminite, resinite and perhydrous vitrinite, and lipid material dispersed in the collodetrinite (Xiao and Ren 1988). According to Teichmüller (1983), micrinite first formed in candle coal. Hydrogen-rich maceral with great thermal activity began splitting, discharging liquid hydrocarbon, but due to the low temperature and coal rank, it can not flow and aggregate, so anisotropy micrinite will be formed. However, if the liquid hydrocarbon liquidity gets strong and aggregates together, anisotropic carbon will form and it appears in XYG6-5.

The content of liptinite (8.89\%) in No. 6 coal is higher than that of North China Coal Basin. According to the rearch of Wang (1996), vitrinite content is $60 \%-85 \%$, the inertinite less than $25 \%$, the liptinite $5 \%$ approximately in Taiyuan Formation, North China. The sporinite and cutinite dominate in liptinite with an average content of $3.8 \%-4.11 \%$, respectively. The cutinite is mainly thickwalled cutinite, whereas there is also thin-walled cutinite, mainly lining the collodetrinite.

Minerals are dominanted by kaolinite. Numerous pyrite appeared in XYG6-2, however, it is infrequent in other samples.

\subsection{Characteristics of coal facies}

Coal facies were delimited by R. Teichmüller and M. Teichmüller (Stach et al. 1982). It is an original cause of formation type which depends on coal plant community and mire environment. The structure index of coal face was presented by Diessel (1986). 
Table 2 The coal facies parameters of the No. 6 coal seam

\begin{tabular}{lllll}
\hline Sample & TPI & GI & VI & GWI \\
\hline XYG6-7 & 1.5 & 2.58 & 1.28 & 0.11 \\
XYG6-6 & 1.43 & 2.81 & 0.75 & 1.2 \\
XYG6-5 & 1.06 & 3.04 & 0.87 & 0.67 \\
XYG6-4 & 1.22 & 2.68 & 0.75 & 0.48 \\
XYG6-3 & 0.34 & 1.96 & 0.22 & 2.61 \\
XYG6-2 & 0.78 & 3.31 & 0.34 & 2.11 \\
XYG6-1 & 0.64 & 2.36 & 0.3 & 5.39 \\
Average & 1 & 2.64 & 0.62 & 1.2 \\
\hline
\end{tabular}

TPI (Telinite + Collotelinite + Fusinite + Semifusinite $) /($ Desmocollinite + Macrinite + Inertodetrinite), GI (Vitrinite + Macrinite)/ (Fusinite + Semifusinite + Inertodetrinite), GWI (Corpocollinite + Gelocollinite + Vitrodetrinite + Clay minerals $) /($ Telinite + Collotelinite + Collodetrinite), VI (Telovitrinite + Fusinite + Semifusinite + Funginite $) /($ Detrovitrinite + Inertovetrinite + Cutinite $)$

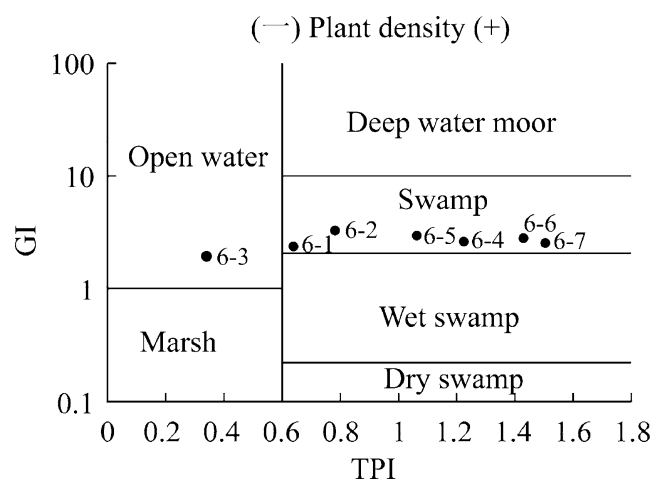

Fig. 4 TPI-GI diagramm

In this study, 4 indices, TPI, GI, VI and GWI are applied (Table 2):

(1) Diessel (1986) drew a GI-TPI diagram to account for the coal forming moors. GI (gelification index) mainly indicates degree of peat bogs and its duration, and from low to high GI value reflects the coal forming environment from dry to wet, and swamp water from shallow to deep. TPI (Tissue Preservation Index) reflects the degradation of plant tissue and woody plants account for the proportion of raw coal plants (Dai et al. 2007). From low to high, TPI reflects the structure of plant cell damage from high to low. All GI and TPI values of the samples from the No. 6 coal were put into Table 2. 6 samples occur in the swamp, only XYG6-3 is in the open water.

(2) GWI (Groundwater Flow Index) and VI (Vegetation Index) are good parameters to response the coal plants, bog medium conditions and sedimentary environment information during peat accumulation

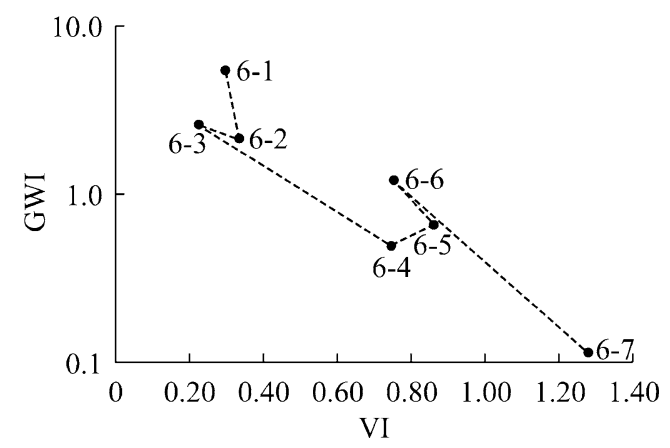

Fig. 5 VI-GWI diagramm

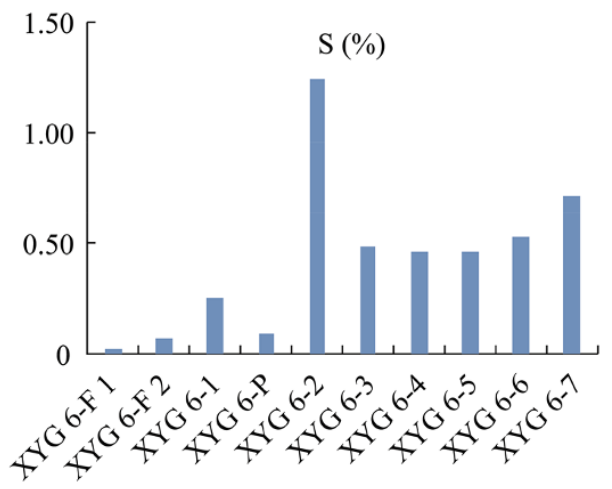

Fig. 6 Total sulfur content of the No. 6 coal

(Diessel 1982; Teichmüller 1989; Gmur and Kwiecińska 2002). GWI is used to reflect on the controlling extent of peat swamp by groundwater; VI shows the species of coal plants and its saving extent (Calder et al. 1991).

Greater GWI indicates stronger water impaction. VI $>1$ indicates that the dominated pants are woody plants, otherwise herbaceous plants. The Fig. 3 shows 6 samples occur in woody plants and only XYG6-7 belongs to woody plants. The GWI values turn down from XYG6-1 to XYG6-7. GWI-VI shows from XYG6-1 to XYG6-7, plants convert from herbaceous to woody plants, at the same time water impact drops as shown in Figs. 4, 5.

\subsection{Geochemical features}

The main components of coal ash are major elements whose content can be used to calculate the parameters of ash composition, which are often used as the determining indexes of sedimentary environment (Ye et al. 1997; Dai 2005). Here are some parameters (Table 5) which includes $\mathrm{S}, \mathrm{Fe}_{2}$ $\mathrm{O}_{3}+\mathrm{CaO}+\mathrm{MgO}, \quad \mathrm{SiO}_{2}+\mathrm{Al}_{2} \mathrm{O}_{3}, \quad\left(\mathrm{Fe}_{2} \mathrm{O}_{3}+\mathrm{CaO}+\right.$ $\mathrm{MgO}) /\left(\mathrm{SiO}_{2}+\mathrm{Al}_{2} \mathrm{O}_{3}\right)$. Some major elements abundances are listed in the Table 3. 
Table 3 Part of major elements abundances of the No. 6 coal seam

\begin{tabular}{lcccccc}
\hline & $\mathrm{Ad}$ & $\begin{array}{l}\mathrm{Fe}_{2} \mathrm{O}_{3} \\
(\%)\end{array}$ & $\begin{array}{l}\mathrm{CaO} \\
(\%)\end{array}$ & $\begin{array}{l}\mathrm{SiO}_{2} \\
(\%)\end{array}$ & \multicolumn{1}{c}{$\begin{array}{l}\mathrm{Al}_{2} \mathrm{O}_{3} \\
(\%)\end{array}$} & $\begin{array}{l}\mathrm{MgO} \\
(\%)\end{array}$ \\
\hline XYG6-7 & 6.53 & 0.28 & 0.07 & 2.86 & 2.61 & 0.02 \\
XYG6-6 & 3.96 & 0.09 & 0.19 & 1.69 & 1.06 & 0.06 \\
XYG6-5 & 4.25 & 0.07 & 0.18 & 2.88 & 1.45 & 0.07 \\
XYG6-4 & 6.17 & 0.36 & 0.10 & 2.86 & 2.61 & 0.02 \\
XYG6-3 & 38.65 & 0.55 & 0.11 & 20.67 & 16.04 & 0.07 \\
XYG6-2 & 34.01 & 1.86 & 0.09 & 15.71 & 13.75 & 0.04 \\
XYG6-1 & 40.67 & 2.98 & 0.09 & 18.21 & 17.35 & 0.07 \\
Average & 19.18 & 0.88 & 0.12 & 9.27 & 7.84 & 0.05 \\
\hline
\end{tabular}

Through studying the modern freshwater, brackish water and salt water of peat bogs, many researchers found that sulfur (S) is relatively high in peat swamp nearby coast, and the $S$ in peat formed in sea is higher than the peat in freshwater, so the S content in coal is a good indicator in identifying paleosalinity (Tang et al. 1996). The weighted mean total sulfur content of the No. 6 coal is $0.73 \%$ in Jungar (Dai et al. 2006). According to Table 4, with the exception of sample XYG6-2 (Fig. 6), a medium sulfur coal (1.26\% total sulfur), all other samples are low-sulfur coal (under $1 \%$ ) which precisely corresponds to the characteristics of the Jugar coalfield in the period of transition.

The content of some trace elements, especially the ratios of some related elements $(\mathrm{Sr} / \mathrm{Ba}$ in this paper) are good signs for distinguishing sedimentary environment (Zhao 1998). $\mathrm{Sr} / \mathrm{Ba}$ is usually less than 1 in freshwater sediments, otherwise which in marine sediments is greater than 1 (Liu et al. 1991), but $\mathrm{Sr} / \mathrm{Ba}$ varies in different regions and

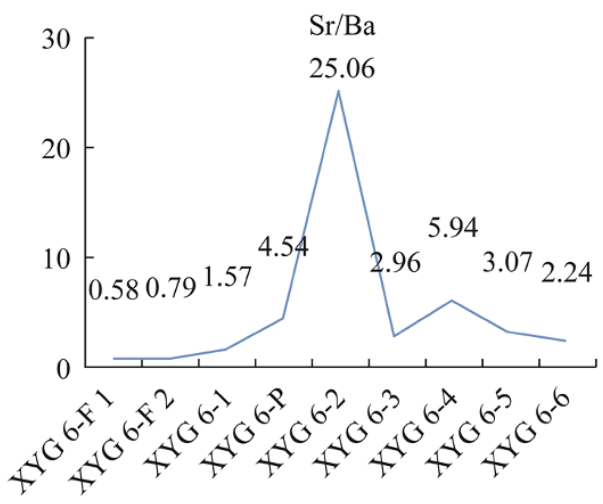

Fig. $7 \mathrm{Sr} / \mathrm{Ba}$ of the No. $6 \mathrm{coal}$

different geological era sediments. However, the same characteristic is the higher $\mathrm{Sr} / \mathrm{Ba}$, the greater salinity. The average value of $\mathrm{Sr} / \mathrm{Ba}$ in Taiyuan Formation, Jungar Coalfield is 4.8 which varies from 0.7 to 16.7 (Liu et al. 1991). Based on the Fig. 7, with the exception of sample XYG6-2, all others are under or close to 4.8 , which means it is a transitional environment.

The ash index of coal (acid-base ratio) $\left(\mathrm{Fe}_{2} \mathrm{O}_{3}+-\right.$ $\mathrm{CaO}+\mathrm{MgO}) /\left(\mathrm{SiO}_{2}+\mathrm{Al}_{2} \mathrm{O}_{3}\right)$ is a parameter for judging sedimentary environment with 0.23 as a critical value (Ye et al. 1997). $Y=\mathrm{CaO} /\left(\mathrm{CaO}+\mathrm{Fe}_{2} \mathrm{O}_{3}\right)$ can reflect the salinity of the sedimentary water medium, and the higher $Y$, the higher salinity. These parameters in Table 5 indicate that the sedimentary environment tended to a terrestrial transition.

According to these parameters, combined with the characteristics in Jungar coalfield, it indicates that the corresponding depositional environment of No. 6 in Xiaoyugou coal mine, Jungar coalfield is in transitional nature from marine to continental facies.

Table 4 Associated elements parameters of the No. 6 coal seam

\begin{tabular}{llllllllllll}
\hline & XYG6-F1 & XYG6-F2 & XYG6-1 & XYG6-P & XYG6-2 & XYG6-3 & XYG6-4 & XYG6-5 & XYG6-6 & XYG6-7 & Average \\
\hline $\mathrm{S}(\%)$ & 0.01 & 0.08 & 0.27 & 0.09 & 1.26 & 0.49 & 0.48 & 0.48 & 0.54 & 0.73 & 0.44 \\
$\mathrm{Sr} / \mathrm{Ba}$ & 0.58 & 0.79 & 1.57 & 4.54 & 25.06 & 2.96 & 5.94 & 3.07 & 2.24 & - & 5.19 \\
\hline
\end{tabular}

Table 5 Parameters of ash compositions for No. 6 coal accumulation environment (after Ye et al.)

\begin{tabular}{|c|c|c|c|c|c|c|}
\hline \multirow[t]{2}{*}{ Sedimentary environment } & \multirow[t]{2}{*}{$\mathrm{A}_{\mathrm{d}}(\%)$} & \multirow[t]{2}{*}{$\mathrm{S}_{\mathrm{t}, \mathrm{d}}(\%)$} & \multicolumn{4}{|c|}{ Ash composition parameter } \\
\hline & & & $\begin{array}{l}\mathrm{CaO} /(\mathrm{CaO} \\
\left.+\mathrm{Fe}_{2} \mathrm{O}_{3}\right)\end{array}$ & $\begin{array}{l}\mathrm{Fe}_{2} \mathrm{O}_{3}+\mathrm{CaO} \\
+\mathrm{MgO}(\%)\end{array}$ & $\mathrm{SiO}_{2}+\mathrm{Al}_{2} \mathrm{O}_{3}(\%)$ & $\begin{array}{l}\left(\mathrm{Fe}_{2} \mathrm{O}_{3}+\mathrm{CaO}+\mathrm{MgO}\right) / \\
\left(\mathrm{SiO}_{2}+\mathrm{Al}_{2} \mathrm{O}_{3}\right)\end{array}$ \\
\hline Peat bogs affected by seawater & $<10$ & $>1$ & Low & $>20$ & $<75$ & $\geq 0.23$ \\
\hline Terrestrial peat bogs & $>10$ & $<1$ & High & $5-20$ & $>75$ & $\leq 0.22$ \\
\hline Average & 19.18 & 0.61 & 0.30 & 1.05 & 17.11 & 0.08 \\
\hline
\end{tabular}




\section{Conclusions}

(1) The high amount of micrinite indicates there may be abundant hydrogen-rich maceral in No. 6 coal with great thermal activity which turned into micrinite. Anisotropic carbon appeared in XYG6-5 may come from liptinite.

(2) The maceral composition, combined with geochemistry parameters results, indicate that lower part of the No. 6 coal in Xiaoyugou mine, Jungar Coalfield was deposited in a transitional environment from marine to continental facies, and it was a transition from barrier island system to tidal-flat facies. The plants transformed from herbs to woody plants and upper water drops.

Open Access This article is distributed under the terms of the Creative Commons Attribution License which permits any use, distribution, and reproduction in any medium, provided the original author(s) and the source are credited.

\section{References}

Calder JH, Gibbing MR, Mukhopadhay PK (1991) Peat formation in a Westphalian B pidemont setting. Bulletin de la Société Géologique de France 7(5):283-298

Dai SF, Ren DY, Tang YG (2005) Modes of occurrence of major elements in coal and their study significance. Coal Geol Explor 33(2):01-05 (in Chinese with English abstract)

Dai SF, Ren DY, Li SS (2006a) The discovery of the superlarge Ga ore deposit in Jungar, Inner Mongolia. Chin Sci Bull 51(2): 177-185

Dai SF, Ren DY, Chou CL, Li SS, Jiang YF (2006b) Mineralogy and geochemistry of the No. 6 coal (Pennsylvanian) in the junger coalfield, ordos basin China. Int J Coal Geol 66:253-270

Dai SF, Ren DY, Li SS, Zhao L, Zhang Y (2007) The succession characteristics of coal facies In Heidaigou, Junger Coalfield, Inner Mongolia. Sci China (D volume: Earth Sciences), S1:119-126. (in Chinese with English abstract)

Dai SF, Li D, Chou CL, Zhao L, Zhang Y, Ren DY, Ma YW, Sun YY (2008) Mineralogy and geochemistry of boehmite-rich coals: new insights from the Haerwusu Surface Mine, Jungar Coalfield, Inner Mongolia, China. Int J Coal Geol 74:185-202

Diessel CFK (1982) An appraisal of coal facies based on macerals characteristics. Aust Coal Geol 4:474-483

Diessel CFK (1986) The correlation between coal facies and depositional environments. In: Proceedings Symposium on Advances in the study of the Sydney Basin, University of Newcastle, Newcastle, 19-22

Gmur D, Kwiecińska BK (2002) Facies analysis of coal seams from the Cracow sandstone series of the upper Silesia Coal Basin, Poland. Int J Coal Geol 25:29-44

Liu HJ, Zhang YJ, Wang HW, Jia YY, Long YZ (1991) Study on lithofacies paleogeography of coal-bearing formations from Junger Coalfield. Geological Publishing House, Beijing (in Chinese with English abstract)
Seredin VV, Dai SF, Sun YZ, Chekryzhov IY (2013) Coal deposits as promising sources of rare metals for alternative power and energy-efficient technologies. Appl Geochem 31:1-11

Stach E, Mackowsky M, Teichmüller M, Taylor GH, Chandra D, Teichmüller R (1982) Coal petrology. Gebrüder, Berlin, p 535

Sun YZ (2003) Petrologic and geochemical characteristics of "barkinite" from the Dahe mine, Guizhou Province, China. Int J Coal Geol 56:269-276

Sun YZ, Püttmann W, Kalkreuth W, Horsfield B (2002) Petrologic and geochemical characteristics of seam 9-3 and seam 2, Xingtai Coalfield, Northern China. Int J Coal Geol 49:251-262

Sun YZ, Liu CY, Lin MY, Li YH, Qin P (2009) Geochemical evidences of natural gas migration and releasing in the Ordos Basin, China. Energy Explor Exploit 27(1):1-13

Sun YZ, Li YH, Zhao CL, Lin MY, Wang JX, Qin SJ (2010a) Concentrations of lithium in Chinese coals. Energy Explor Exploit 28(2):97-104

Sun YZ, Qin SJ, Zhao CL, Kalkreuth W (2010b) Experimental study of early formation processes of macerals and sulfides. Energy Fuels 24:1124-1128

Sun YZ, Zhao CL, Li YH, Wang JX, Liu SM (2012a) Li distribution and mode of occurrences in Li-bearing coal seam $6^{\#}$ from the Guanbanwusu Mine, Inner Mongolia Northern China. Energy Explor Exploit 30(1):109-130

Sun YZ, Yang JJ, Zhao CL (2012b) Minimum mining grade of associated Li deposits in coal seams. Energy Explor Exploit 30(2):167-170

Sun YZ, Zhao CL, Li YH, Lin MY, Püttmann W (2012c) Relationship between lithium enrichment and organic matter in Coal Seam 6 from the Guanbanwusu Mine, Inner Mongolia, China. 29th Annual Meeting of the Society for Organic Petrology. Progr Abstr 29:114-116

Sun YZ, Zhao CL, Li YH, Wang JX, Zhang JY, Jin Z, Lin MY, Kalkreuth W (2013) Further information of the associated Li deposits in the No. 6 coal seam at Jungar Coalfield, Inner Mongolia, northern China. Acta Geol Sinica 87(4):801-812

Tang YG, Ren DY, Liu QF, Yao GH, Gan ZJ (1996) Relationship between the coal-forming environment and sulfur in the Late Permian coal of Sichuan, China. Acta Sedimentol Sin 04: 162-168 (in Chinese with English abstract)

Teichmüller M (1983) The generation of oil material in the coal seam under the microscope. petroleum geology memoir (in Chinese with English abstract)

Teichmüller M (1989) The genesis of coal from the viewpoint of coal petrology. Int J Coal Geol 12:1-87

Wang YB (1996) The maceral characteristics of the main coalaccumulating periods, China. China University of Mining and Technology Press, Xuzhou, pp 108-111 111 (in Chinese with English abstract)

Xiao XM, Ren DY (1988) A discovery of the anisotropic micrinite in the late paleozoic coal seams of western Henan coal field and the discussion on its origin. J China Univ Min Technol 01:80-86

Ye DM, Luo JW, Xiao WZ, Wang SJ (1997) Origin and application of maceral in southwestern China. Geological Publishing House, Beijing (in Chinese with English abstract)

Zhao FH, Ren DY, Zhang JY, Dai SF (1998) Recent advance of study on hazardous elements in coal and significance for environmental protection. Environl Prot Coal Mine 12(2):20-23 (in Chinese with English abstract)

Zhao CL, Sun YZ, Xiao L, Qin SJ, Wang JX, Duan DJ (2014) The occurrence of barium in Jurassic coal in the Huangling 2 Mine, Ordos Basin, northern China. Fuel 128:428-432 